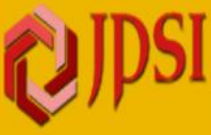

E-ISSN: 2622-1837

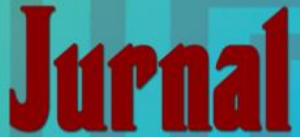

Pendidikan Sejarah Indonesia

\section{PERAN DAN PARTISIPASI MASYARAKAT DALAM UPAYA PEMANFAATAN CAGAR BUDAYA DI KABUPATEN BONDOWOSO SEBAGAI SUMBER BELAJAR SEJARAH LOKAL DAN ASET UNGGULAN DAERAH}

\author{
Blasius Suprapta \\ blasius.suprapta.fis@um.ac.id
}

Jurusan Sejarah, Universitas Negeri Malang, Indonesia Tim Ahli Cagar Budaya, Jawa Timur, Indonesia

ARTICLE INFO:
Conceptual Article
Article history:
Received 31 May 2020
Revised 21 June 2020
Accepted 21 June 2020
Published 30 June 2020
Available online 30 June 2020
C)2020. JPSI. All rights reserved.

\begin{abstract}
Bondowoso, as one of the regions of East Java Province, has the potential of cultural heritage from the various era: megalithic, Hindhu-Buddhist, colonial, and the struggle for the defense of Indonesian independence. However, the potential of cultural heritage, which is known to be spread throughout the district (kecamatan) in Bondowoso, has not been utilized as a source of local history instruction or as a vital asset of the region. For this reason, it is necessary to find a solution for modeling the use of cultural heritage as a source of historical learning and study of superior regional assets to foster the participation of local communities based on the preservation of cultural heritage for the welfare of the communities around the cultural heritage. The method used is to adopt the modeling of the use of cultural heritage, namely Malang Kembali event, the colorful village event of Jodipan Village, Malang City, the development of revitalization of the Majapahitan house in Trowulan and the Mount Pawitra adventure event. The results of the study show that the four models are suitable to be applied in Bondowoso to foster the role of the community around cultural heritage for the use of cultural heritage as a source of learning of Local History and superior regional assets in Bondowoso Regency, based on the preservation of cultural heritage.
\end{abstract}

Keywords: cultural heritage, Bondowoso, Local History sources, leading asets of the region, community empowerment 


\section{PENDAHULUAN}

Pemanfaatan cagar budaya diatur dalam Pasal 1 ayat (33) dan Pasal 85, serta Pasal 86, Undang Undang Republik Indonesia Nomor 11 Tahun 2010 tentang Cagar Budaya. Dalam Pasal 1 ayat (33) disebutkan bahwa Pemanfaatan adalah pendayagunaan cagar budaya untuk kepentingan sebesarbesarnya kesejahteraan rakyat dengan tetap mengedepankan kelestariannya. Dalam Pasal 85 ayat (1) disebutkan bahwa Pemerintah, Pemerintah Daerah dan setiap orang dapat memanfaatkan cagar budaya untuk kepentingan agama, sosial, pendidikan, ilmu pengetahuan, teknologi, kebudayaan dan pariwisata. Kemudian pada ayat (2) dikemukakan bahwa Pemerintah dan Pemerintah Daerah memfasilitasi pemanfaatan dan promosi cagar budaya yang dilakukan oleh setiap orang. Pada ayat (3) disebutkan bahwa Fasilitasi sebagaimana yang dimaksud pada ayat (2) berupa izin Pemanfaatan, dukungan Tenaga Ahli Pelestarian, dukungan dana, dan/atau pelatihan. Adapun yang dimaksud dengan promosi cagar budaya, dalam ayat (4) dikemukakan bahwa promosi yang dimaksud pada ayat (2) dilakukan untuk memperkuat identitas budaya serta meningkatkan kualitas hidup dan pendapatan masyarakat (Undang-Undang Republik Indonesia Nomor 11 Tahun 2010 Tentang Cagar Budaya).

Sesuai apa yang digariskan dalam Undang-Undang RI Nomor 11 Th. 2010, dalam menggiatkan pemanfaatan cagar budaya untuk meningkatkan kualitas hidup dan pendapatan masyarakat sekurang-kurangnya ada tiga hal yang harus diperhatian yaitu Peran Pemerintah Daerah, Tenaga Ahli Pelestari dan peran serta partisipasi masyarakat termasuk bidang pemanfaatan cagar budaya sebagai sumber belajar sejarah lokal (Sayer, 2015). Pengertian masyarakat di sini dapat berupa peran serta partisipasi perseorangan, pendidik, peserta didik serta masyarakat sekitar di lingkungan cagar budaya. Bagaimanakah keempat hal itu dapat saling berhubungan serta saling terjalin dengan baik, sehingga pemanfaataan cagar budaya untuk memperkuat identitas budaya khususnya identitas Budaya Kabupaten Bondowoso, sumber belajar sejarah lokal serta kepentingan peningkatan kualitas hidup serta pendapatan masyarakat khususnya masyarakat Kabupaten Bondowoso di sekitar cagar budaya dapat terwujud sesuai dengan harapan Undang-Undang RI No.11 Th.2010. Pada kegiatan ini, akan penulis coba untuk mendiskusikan tentang jalan keluar tentang peran serta partisipasi masyarakat perihal pemanfaatan cagar budaya di Kabupatan Bondowoso sebagai aset unggulan daerah dan aset sumber belajar sejarah lokal berbasis pada pelestarian serta revitalisasi cagar budaya di Bondowoso. Penulis akan mendiskusikan dengan beberapa model tentang peran serta partisipasi masyarakat dalam hal pemanfatan cagar budaya sebagai aset unggulan daerah dan aset sumber belajar sejarah lokal. Model yang penulis ajukan yaitu (1) model peran serta partisipasi masyarakat dalam pemanfaatan cagar budaya bangunan Indis untuk event Malang Kembali di Malang, (2) model peran serta partisipasi masyarakat "Revitalisasi Rumah Majapahitan" di lingkungan situs Ibu Kota Majapahit, Trowulan, dan (3) model serta partisipasi masyarakat Kampung Warna-Warni di Kapung Jodipan, di lingkungan bangunan Indis: Jembatan Rel Kereta Api, di Kota Malang. Sebelum menjangkau tentang diskusi tersebut, terlebih dahulu penulis paparkan potensi 
dan aset unggulan sumber belajar sejarah lokal serta aset unggulan cagar budaya Kabupaten Bondowoso.

\section{POTENSI SERTA ASET UNGGULAN SUMBER BELAJAR SEJARAH LOKAL DAN ASET UNGGULAN CAGAR BUDAYA KABUPATEN BONDOWOSO.}

Bila dikaitkan dengan Undang-Undang RI No.11. Tahun 2010 Tentang Cagar Budaya, yang dimaksud dengan potensi serta aset unggulan sumber belajar sejarah lokal dan aset unggulan cagar budaya Kabupaten Bondowoso yaitu bahwa keberadaan Cagar Budaya (1) mewakili masa gaya paling singkat 50 tahun, (2) memiliki arti khusus bagi sejarah, ilmu pengetahuan, pendidikan, agama dan/atau kebudayaan dan (3) memiliki nilai budaya bagi penguatan kepribadian budaya termasuk di dalamnya sejarah lokal (Undang-Undang RI No.11 Tahun 2010 Tentang Cagar Budaya). Terkait dengan hal tersebut, berdasarkan hasil penelitian para peneliti terdahulu yakni H.E.Steinmetz (1889), H.R.van Heekeren (1931), W.J.A.Willems (1930) dan Tim Balai Arkeologi Yogyakarta (1985-1987), dapat diketahui bahwa cagar budaya Bondowoso dapat dikategorikan berdasarkan masanya yaitu cagar budaya Tradisi Prasejarah berupa bangunan Tradisi Megalitik, cagar budaya Hindhu-Buddha, cagar budaya Indies dan cagar budaya masa Kemerdekaan Indonesia (Soekiman 2000).

Berdasarkan hasil penelitian H.E. Steinmetz, H.R.van Heekeren, W.J.A.Willems serta Balai Arkeologi Yogyakarta, diketahui antara lain bahwa cagar budaya yang berupa kawasan, situs serta bangunan tradisi megalitik adalah yang paling menonjol serta kompleks dan persebarannya hampir merata di seluruh wilayah kecamatan Kabupaten Bondowoso. Adapun cagar budaya dari masa Hindhu-Buddha hanya terbatas di beberapa wilayah kecamatan antara lain di wilayah Kecamatan Praejegan dan Klabang, cagar budaya Indies terkonsentrasi di Kota Bondowoso serta di areal sentrasentra perkembunan yang pernah dikelola Pemerintahan Hindia Belanda. Dengan demikian unggulan aset sumber belajar sejarah lokal serta aset unggulan cagar budaya Bondowoso hampir ditemukan di setiap jenjang masa perkembangan sejarah, sehingga Bondowoso dapat dikategorikan memiliki potensi dan aset unggulan sumber belajara sejarah lokal dan aset unggulan cagar budaya baik yang dapat dikategorikan pada pemeringkatan cagar budaya tingkat Kabupaten, Propinsi, Nasional dan bahkan bisa ditingkatkan ke peringkat internasional.

Pada jenjang Lintasan Sejarah Tradisi Prasejarah, berdasarkan hasil penelitian H.E. Steinmetz (1889), H.R.van Heekeren (1931) dan W.J.A.Willems (1938) temuan obyeks tradisi prasejarah yang paling menonjol yaitu berupa bangunan tradisi megalitik. Obyek megalitik yang dimaksud yaitu terdiri atas bangunan megalitik sarkofagus, dolmen, dolmen sebagai kuburan, kubur bilik batu, kubur batu pandhusa, punden berundak, kelompok batu kenong, patung nenek moyang, lumpang batu, batu dakon, menhir, dan beberapa obyek megalitik lain yang belum teridentifikasi. Salah satu kubur batu yang hanya ditemukan di Bondowoso yaitu jenis kubur batu pandhusa. Berdasarkan hasil penelitian W.J.A.Willems (1938) bangunan megalitik ini, di Indonesia hanya ditemukan di Bondowoso dan beberapa ahli megalitik menyebutan sebagai hasil kepandain setempat (local genius) masyarakat megalitik yang pernah berkembang di kawasan situs Bondowoso. Hasil penelitian Willems tersebut 
dapat dijadikan aset unggulan sumber belajar sejarah lokal, terutama sebagai media belajar yang berhubungan seluk-beluk kehidupan tradisi megalitik yang pernah berkembang meluas di daerah Bondowoso (Suprapta, 2000, 2018, 2019).

W.J.A. Willems pada th.1938, melakukan penelitian intensip terhadap kubur batu pandhusa dan mengambil daerah penelitian di kawasan situs Pakauman, Grujugan, Bondowoso. Willems melalukan pemetaan, deskripsi mendalam peninggalan megalitik, ekskavasi dan melakukan telaah fungsi batu kenong serta struktur bangunan megalitik pandhusa. Willems berhasil melakukan ekskavasi pandhusa I dan pandhusa II dan berhasil menyingkap tentang struktur bangunan kubur batu serta berhasil menemukan tulang-belulang manusia, pecahan-pecahan gerabah, manik-manik, gigi binatang (Bubalis bubalis), fragmnen logam besi dan keramik asing abad IX M. Dalam laporannya diketahui bahwa pandhusa terdiri atas struktur bangunan tutup kubur yang terbuat daribatu monolit dari batuan breksi vulkanik. Kemudian tutup kubur tersebut disangga oleh beberapa balok-balok batu berbentuk empat persegi dan membentuk ruang empat persegi dan di bagian depan dibentuk pintu yang dapat dibuka setiap saat. Arah kubur batu pandhusa yaitu menghadap ke Gunung Yaang, sehingga puncak gunung tersebut diyakini sebagai tempat bersemayamnya rok nenek moyang pendukung kebudayaan megalithik pada waktu itu (Willems, 1938: 31-34). Willems menduga kubur batu pandhusa digunakan kubur lebih dari satu individu seperti halnya kubur batu di Tana Toraja, Sulawesi Selatan. Inilah salah satu unggulan serta potensi cagar budaya Bondowoso dalam lintasan sejarah tradisi Prasejarah. Hal yang dimaksud yaitu jenis bangunan megalitik berupa kubur batu: pandhusa di Indonesia hanya ditemukan di daerah Bondowoso sebagai salah satu ciri khas budaya megalitik yang pernah berkembang di daerah Bondowoso. Aspek ciri khas setempat serta satusatunya jenis kubur batu di Indonesia bahkan di Asia Tenggara ini merupakan suatu ikon potensi serta unggulan cagar budaya di Bondowoso (Gambar 1). Hasil penelitian ini dapat dijadikan sumber belajar sejarah lokal yang sangat penting untuk mengungkap sikap kegotong-royongan yang religius yang pernah berkembang pada masa perkembangan kebudayaan pendirian bangunan-bangunan batu besar di kawasan Bondowoso (Sanjaya, 2014).

Salah satu unggulan bangunan megalitik lainnya yaitu temuan kelompok batu kenong yang akhir-akhir ini banyak diperdepatkan tentang fungsinya. Pedebatan tentang fungsi kelompok batu kenong telah dimulai pada saat H.R.van Heekeren, pada th.1931 menemukan benda aneh yang pada waktu itu oleh kelompok masyarakat Madura di Bondowoso disebut "batu kenong". Disebut "batu kenong" karena bentuk fisik obyek megalitik tersebut dapat disamakan dengan bentuk instrumen musik gamelan Jawa yaitu "kenong". Heekeren (1931:7) menduga kelompok batu kenong ada kemungkinan berhubungan atau difungsikan sebagai kuburan masal - tanpa melalui penelitian yang mendalam. Namun pendapat ini, kemudian terbantahkan oleh hasil penelitian Willems (1938: 41-42) yang melakukan penelitian mendalam tentang kelompok batu kenong I serta kelompok batu kenong II di Grujukan, Pakauman. Dikemukakan oleh Willems bahwa hasil penggalian di lingkungan kelompok batu kenong I serta II, tidak ditemukan sisa-sisa tulang manusia, bekas liang lahat serta bekal kubur. Hasil ekskavasi Willems, terutama pada kompleks kelompok batu kenong I, berhasil ditemukan pecahan-pecahan gerabah sama jenis dengan jenis pecahan gerabah pandhusa II, manik- 
manik, gelang besi, serta alat kayu yang kemungkinan merupakan rajah pertanggalan serta pecahanpecahan keramik asing abad IX $\mathrm{M}$, dengan demikian tidak ada kaitannya dengan masalah penguburan masal seperti yang diduga oleh Heekeren (Gambar 2 dan Gambar 3).

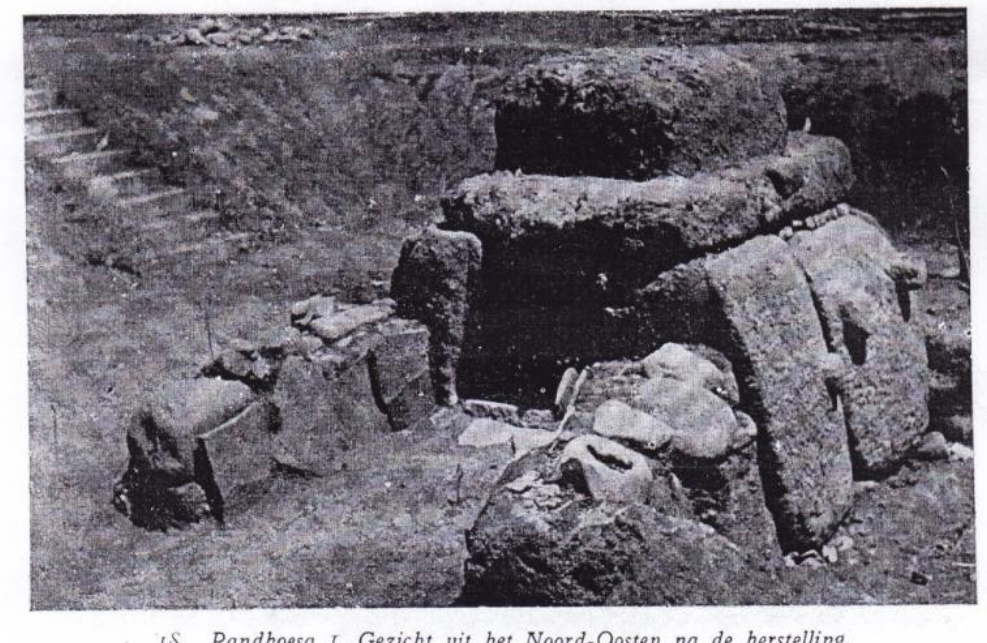

Gambar 1. Pandhusa 1 hasil penggalian Willem Tahun 1938

(Sumber Willems 1938:50)

Dalam perkembangan selanjutnya, hasil ekskavasi Willems tersebut, diperkuat dengan hasil penelitian yang dilakukan oleh Team Balai Arkeologi Yogyakarta th.1985 bahwa di lingkungan kelompok batu kenong ditemukan beberapa fragmen manik-manik, gerabah, fragmen besi berupa mata bajak, keramik asing dan di lingkungan kelompok batu kenong tidak ditemukan sisa-sisa belulang manusia maupun bekas liang lahat. Atas dasar temuan ekskavasi Willems (1938) dan Team Balai Arkeologi Yogyakarta tahhun 1983 - 1985 diperkirakan kelompok batu kenong cenderung berkaitan dengan masalah pemukiman, sehingga dimungkinan sebagai bekas umpak bangunan berpanggung dari bangunan konstruksi kayu. Simpulan ini didukung pula, hasil penelitian Blasius Suprapta (1987) terhadap analisis perbandingan dengan sebaran struktur denah kelopok batu kenong di daerah Grujugan, Tamanan, Tanah Wulan, Kodedek, Curah Poh, serta Jebong Lor, Bondowoso dan sejumlah umpak batu di Situs Watu Gudig, Jawa Tengah, umpak bangunan berpanggung di Tana Toraja. Dengan demikian salah satu fungsi obyek megalitik kelompok batu kenong, kemungkinan berhubungan dengan umpak bangunan berpanggung dari bangunan konstruksi kayu. Temuan persebaran kelompok batu kenong ini dapat dijadikan materi sumber belajar sejarah lokal tentang bagaimana tata cara serta teknologi masyarakat pada waktu itu mendirikan bangunan pemukiman. Hal yang sangat esensial yaitu pengetahuan masayarakat waktu telah memperhitungkan aspek mekanika bangunan yakni membuat bangunan rumah tinggal yang adaptif dengan lingkungan antara lain telah memperhitungkan aspek kegempaan. Ini suatu kearifan lokal masyarakat megalitik di Bondowoso dan merupakan sumber belajar sejarah lokal yang cukup memadai untuk disampaikan pada peserta didik (Sanjaya, 2013, Suprapta, 2017b). 


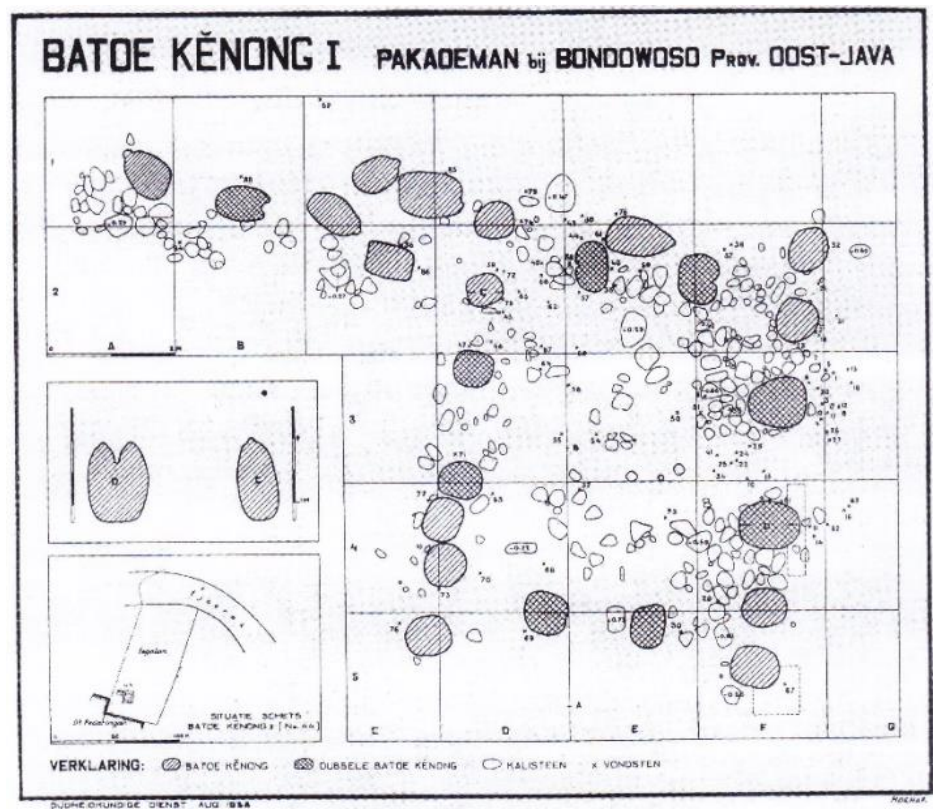

Gambar 2. Susunan Kelompok Batu Kenong 1.

(Sumber: Willems 1938: 40)

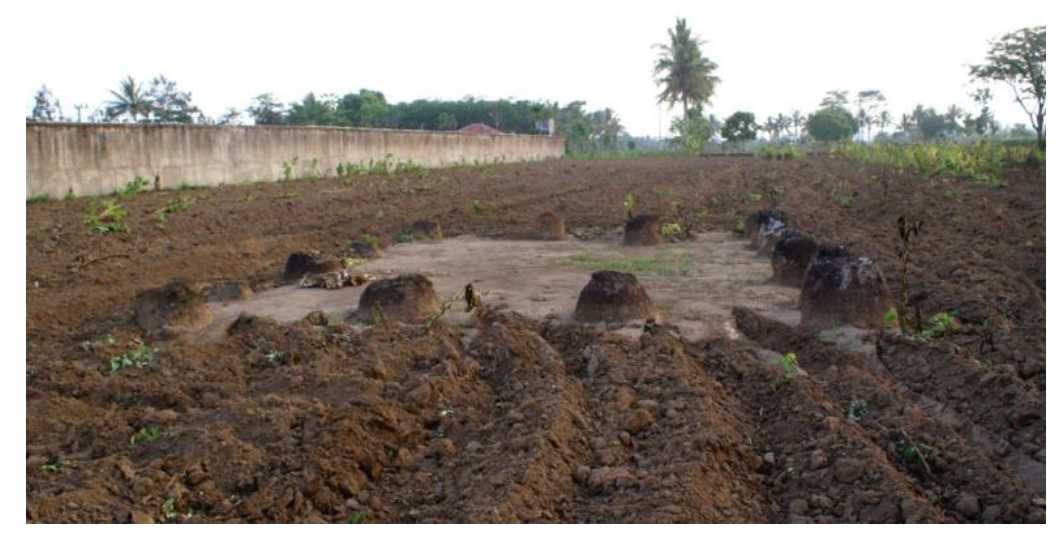

Gambar 3. Susunan Kelompok Batu Kenong 2.

(Sumber: Suprapta, 2018)

Obyek unggulan bangunan megalitik lainnya yaitu komplek kubur batu sarkofagus di Glingseran, Wringin yang oleh masyarakat setempat disebut "watu kendang". Sarkofagus tersebut memiliki bentuk spesifik yakni bagian penutup berbentuk silinder dan bagian wadah berbentuk persegi. Di sisi lain, di lingkungan situs masih dapat ditemukan kembali tentang lokasi penambangan 
bahan baku pembuatan sarkofagus tersebut, sehingga merupakan data unggulan untuk dapat menggambarakan proses pendirian bangunan megalitik di situs tersebut. Tidak jauh dari situs Glingseran, yakni di daerah Banyuputih terdapat temun obyek megalitik yang oleh penduduk setempat disebut " batu labeng" (Gambar 4 dan Gambar 5). Sebetulnya bangunan tersebut berupa dua buah balok batu yang didirikan pada sebuah batu dudukan atau batu alas yang dilubangi. Sejauh pengetahuan penulis, bangunan megalitik ini, hanya di temukan di Bondowoso dan kemungkinan berhubungan dengan kalender musim atau astronomi. Lubang pada tumpuan kedua balok batu tersebut ada kemungkinan untuk melihat titik matahari terbit dalam hubungannya dengan awal musim bercocok tanam, penelitian ke arah ini, saat sekarang baru dalam proses. Namun yang perlu diketahui bahwa berdasarkan arti khusus bagi sejarah termasuk sejarah lokal, ilmu pengetahuan, pendidikan dan kebudayaan, bangunan megalitik kubur batu pandhusa, dolmen sebagai kuburan, sarkofagus, kelompok batu kenong, serta bangunan megalitik "batu labeng" merupakan unggulan cagar budaya lintas sejarah tradisi Prasejarah di Bondowoso (U.U.R.I. No.11 th.2010, Pasal 5).

Perlu diketahui bahwa berdasarkan pertanggalan yang dilakukan oleh Bagyo Prasetyo (2014:89) pada tahun 1996, 1999, 2000 dan tahun 2006 diperkirakan keberlangsungan kebudayaan megalitik megalitik di Bondowoso berkisar pada kurum waktu antara abad VI hingga berakhir abad XI Masehi. Dan khusus di Grujugan, Pakauman berdasakan temuan keramik asing abad IX M, diperkirakan berlangsung hingga abad IX M. Dengan demikian dapat dikemukakan bahwa perkembangan kebudayaan megalitik di Bondowoso berlangsung serta berkembang pada kurun waktu sejarah yakni Masa Hindhu-Buddha abad VI hingga abad XI Masehi atau pada masa perkembangan awal Kerajaan Hindhu-Buddha abad VI di Indonesia hingga menjelang masa HindhuBudha akhir Masa Kerajaan Kadhiri abad XI M (Sumadio 1984:29-37, 272-273).

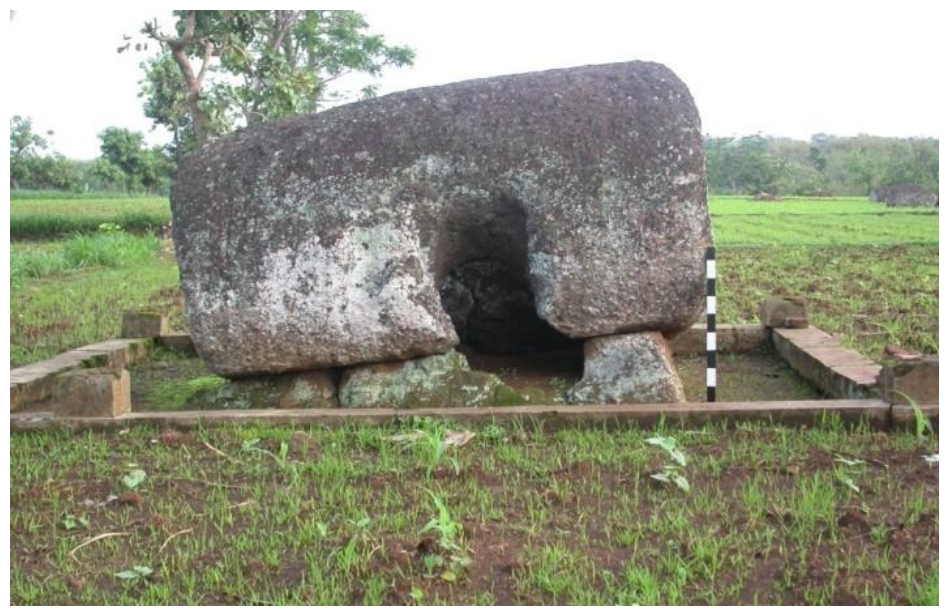

Gambar 4. Salah satu kubur batu Sarkofagus di Situs Glingseran, Wringin

](Sumber: Suprapta, 2019) 


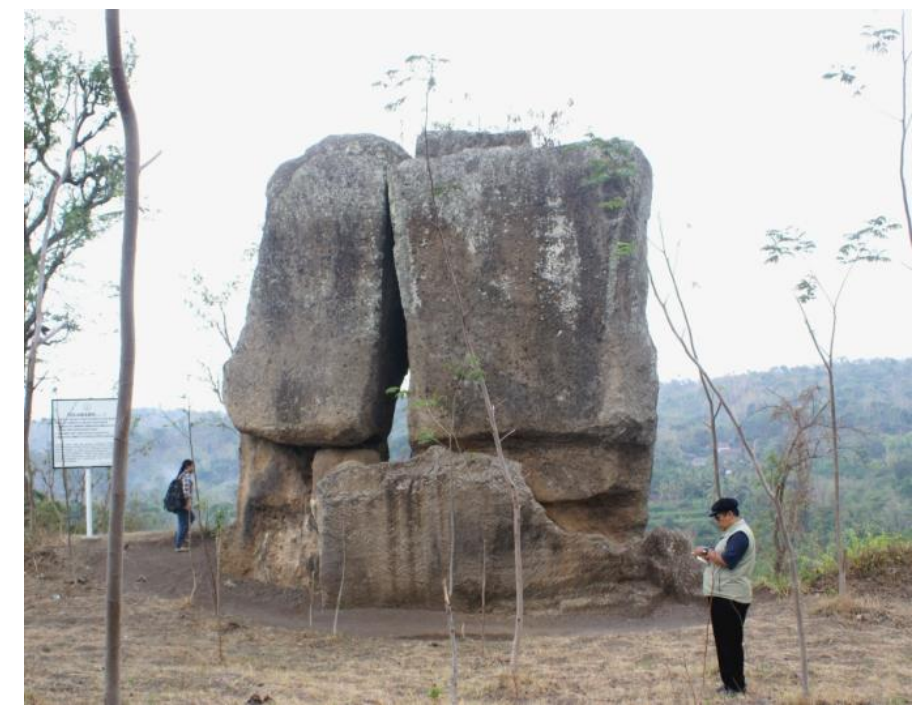

Gambar 5. Sepasang menhir berukuran besar "batu labeng” di Situs Banyuputih

(Sumber: Suprapta 2018)

Berdasarkan rekonstruksi kehidupan megalitik, sebaran bangunan megalitik yang memiliki unggulan tersebut dapat menggambarkan keungulan kebudayaan megalitik pada kurum waktu abad VI - XI M di Bondwoso. Berdasarkan konsepsi pendirian bangunan megalitik, diyakini bahwa di Bondowoso telah berkembang pesat tentang keyakinan akan penghormatan roh nenek moyang. Para pendukung kebudayaan megalitik pada waktu itu mempercayai kehidupan setelah kematian, sehingga sangatlah menonjol tentang upcara yang berkaitan dengan proses kematian, mengantarkan si mati ke alam kematian atau alam roh nenek moyang. Pada waktu orang meninggal dunia, kemungkinan si mati tidak langsung dikuburkan, namun dikuburkan dalam kubur sementara. Setelah persiapan untuk mengantarkan roh si mati ke alam setelah kematian, dianggap siap, termasuk dalam hal ini persiapan pembuatan kubur batu, perlengkapan upacara penguburan, maka si mati dikuburkan ke dalam kubur batu dengan upacara sangat sakral. Proses pembuatan kubur batu seperti pandhusa, sarkofagus, kubur bilik (Suprapta, 2019) serta kubur dolmen memakan waktu yang sangat lama dan dikerjakan secara bergotong royong antar sesame pendukung kebudayaan megalitik. Dengan demikian bangunan megalitik mencerminkan atau penanda solidaritas masayarakat yang sangat tinggi (Praseyo, 2014: 16-19). Hal ini dapat dijadikan sumber belajar sejarah lokal yang berkaitan dengan seluk-beluk kehidupan sosial serta religi pada masa keberlangsungan budaya pendirian batu-batu besar atau megalitik.

Setelah si mati diletakkan ke dalam kubur batu dan di arah ke puncak gunung, maka didirikan lambang si mati berupa patung nenek-moyang atau menhir sebagai lambang si mati dan sekaligus sebagai penanta perantara yang menghubungkan si mati yang telah berada di alam setelah kematian dengan keluarga yang masih hidup di dunia. Oleh karena puncak gunung diyakini sebagai tempat tinggal roh nenek-moyang mereka, maka puncak-puncak gunung yang berada di lingkungan Bondowoso waktu itu dianggap sakral, maka dilarang untuk dirusak, dikotori atau dimusnakan. Di 
sisi lain gunung-gunung tersebut mendatangkan kesuburan bagi ternak dal lahan pertanian mereka, karena gunung-gunung tersebut mengeluarkan sumber-sumber air yang menghidupi seluruh makluk hidup termasuk hewan piaraan serta sumber daya makanan hayati (Soejono 1984: 204 - 212). Iniliah potensi serta keunggulan cagar budaya Megalitik Bondowoso untuk pembentukan identitas budaya Bondowoso dan hal inilah yang perlu dikomunikasikan untuk dikemas dalam bentuk "enovasi" destinasi wisata untuk menghidupkan peran serta partisipasi masyarakat dalam kaitannya dengan peningkatan kesejahteraan masyarakat di sekitar cagar budaya (Handini 2012: 135-149).

Dalam masa lintasan sejarah perkembangan Hindhu-Budha keunggulan cagar budaya di Bondowoso ditandai dengan ditemukannya situs Gua Pertapaan Sukorejo, Kecamatan Sumberwringin serta situs Gua Pertapaan Jirek Mas, Kecamatan Cerme (Sie Kesejarah dan Purbakala Bondowoso 2017). Situs Gua Pertapaan Sukorejo, Kecamatan Sumberwringin, memuat angka tahun 1241 Caka atau 1319 Masaehi 1dan sebuah pahatan kala gaya Jawa Timuran. Hal ini membuktikan bahwa menjelang abad XI hingga abad XIV Masehi telah berkembang kebudayaan bercorak HindhuBuddha di Bondowoso, sehingga situs Gua Pertapaan Sukorejo memiliki arti khusus bagi sejarah, bagi ilmu pengetahuan, pendidikan, perkembangan keagamaan dan sejarah kebudayaan (Gambar 6).

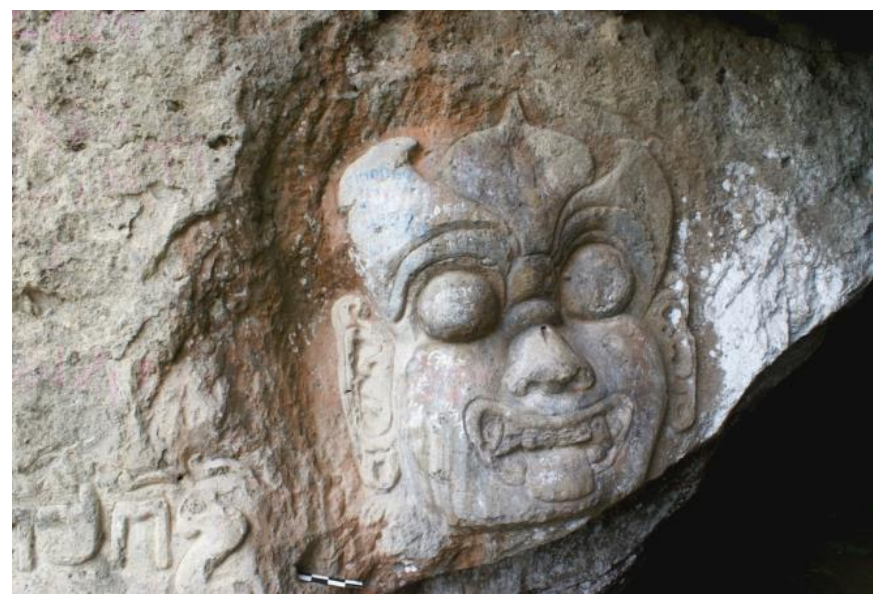

Gambar 6. Gua pertapaan Jirek Mas, Kec. Cerme, memuat angkat tahun 1241 Çaka

(Sumber: Suprapta, 2018)

Dari berbagai kajian literatur salah satu fungsi gua pertapaan adalah berhubungan dengan tingkatan-tingkatan kehidupan keluarga dalam agama Hindhu. Hal yang dimaksud yaitu tingkatan caturāçrama terdiri atas tingkatan brahmaçārin, grhastha, wānaprastha dan sanyasin atau pariwrājaka. Pada jenjang kehidupan anak umur 8 - 12 tahun, anak diserahkan kepada seorang ācārya atau guru. la menjalani tingkatan kehidupan brahmacārin, ia harus tunduk pada guru. Pada tingkatan kehidupan umur 10 - 12 tahun tamatlah ia belajar, maka ia pulang ke rumah orang tuanya, untuk segera menjalani kewajiban untuk memasuki tingktan kehidupan grhastha atau kepala keluarga, maka ia berhak menyelenggarakan upacara saji. Seletah memasuki tingkatan kehidupan yaitu

1) Hasil pembacaan Ismail Lutfi 2017 
memiliki cucu yang pertama, maka ia sendiri atau istrinnya, meninggalkan kehidupan duniawi dan mengundurkan diri ke dalam hutan-hutan sebagai wānaprāstha yakni penghuni hutan. Di lingkungan hutan ini ia bertapa di gua-gua pertapaan serta merenungkan hidup sedalam-dalamnya. Pada tingkatan kehidupan terakhir yaitu memasuki tingkatan kehidupan sanyasin yaitu kewajiban kehidupan terakhir dengan melakukan aktifitas pengembaraan tanpa sesuatu harta milik dan ia selalu berjalan dengan tak tentu tujuan sampai akhirnya ia mati (Soekmono 1973: 12-13).

Apabila dikaitkan dengan tingkatan-tingkatan kehidupan dalam kehidupan Agama Hindhu tersebut, maka keberadaan Gua Pertapaan Sukorejo serta Gua Jirek Mas memeliki arti penting bagi ilmu pengetahuan yaitu mengungkapkan adanya kehidupan masyarakat Hindhu pada tingkatan kehidupan wanaprasta serta sanyasin. Dengan demikian keberadaan kedua situs tersebut dapat dikategorikan sebagai cagar budaya yang memiliki aset keunggulan ditinjau dari penanda masa, arti khusus bagi sejarah termasuk sumber belajar sejarah lokal, ilmu pengetahuan, perkembangan keagamaan, pendidikan dan memiliki nilai budaya bagi penguatan kepribadian budaya bangsa, khususnya dalam lingkup nilai budaya di Kabupaten Bondowoso. Di sisi lain keberadaan gua tersebut pada abad XIV M atau masa bersamaan dengan masa Majapahit akhir merupakan hutan primer serta jauh dari pemukiman dan terntunya berlokasi dengan lingkungan alam kesunyian dan bila hal ini dikumunikasikan pada publik maka dapat dikembangkan sebagai desnitasi wisata berhubungan desnitasi minat khusus aventura serta arkeologis atau wisata kesejarahan (Ardika 2012:23-33).

Cagar budaya dalam lintasan Sejarah Masa Kolonial, seperti telah dikemukakan di muka antara berupa bangunan kolonial dalam kaitannya perkembangan perkebunan masa kolonial seperti berupa Pabrik Gua Prajegan, Statiun Kereta Api Bondowoso, serta rumah-rumah kolonial dalam hubungannya dengan perkebunan kopi seperti di Sumberwringin. Aset keunggulan cagar budaya kolonial tersebut dapat dijadikan aset desnitasi wisata keluarga, agrowisata, wisata museum dan wisata kuliner yang dapat meningkatan pendapatan masyarakat. Dengan demikian perlu dikemas pengembangan secara sinergi tentang aset unggulan cagar budaya Kolonial, mengingat di daerah Bondowoso pada masa Kolonial dikembangkan sebagai wilayah untuk pengembangan agribisnis utama perkebunan tebu serta kopi (Leirissa, 1984).

Cagar budaya dalam lintasan Sejarah Masa Kemerdekaan Repuplik Indonesia berupa ingakatan kolektif yang dikenal dengan peristiwa heroik "Gerbong Maut" yang merupakan aset unggulan ingkatan kolektif atau bisa dikategorikan warisan budaya tak benda: "intangible cultural heritage". Warisan budaya tak benda yang mengandung nilai-nilai perjuangan bangsa atau nasionalisme tersebut telah diwujudkan dalam bentuk Monomen Gerbong Maut yang terkenal di seluruh Indonesia (Prayoga et.al, 1986: 50-62). Penempatan "Monumen Gerbong Maut" adalah di tengah kota Bondowoso, tepat di tengah-tengah alon-alon Kota Bondowoso (Gambar 7 dan Gambar 8). 


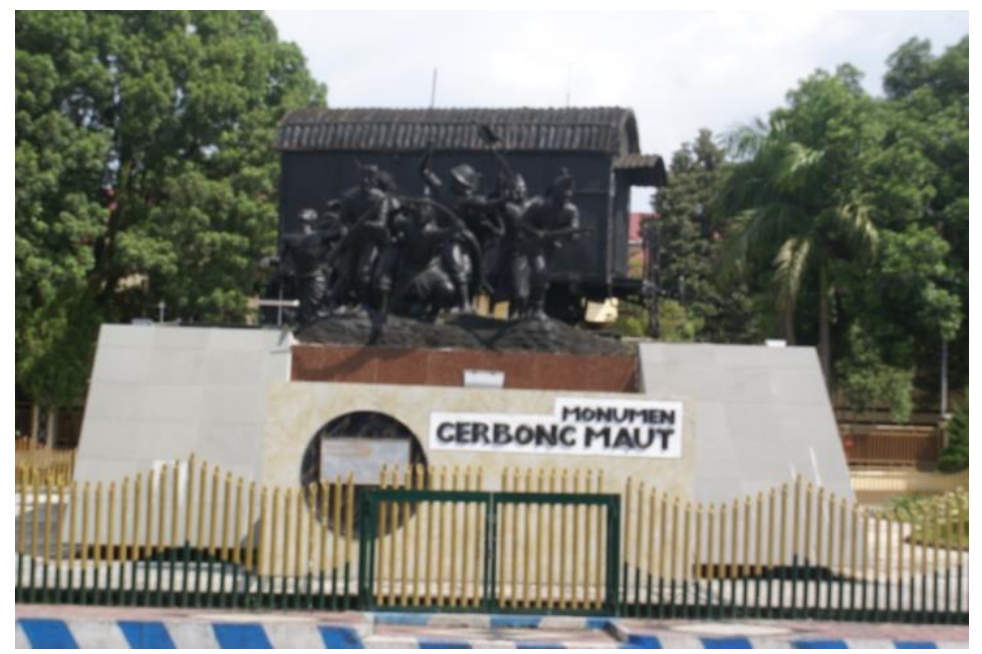

Gambar 7. Monumen "Gerbong Maut” di Alon-alon Kota Bondowoso

(Sumber: Suprapta, 2018)

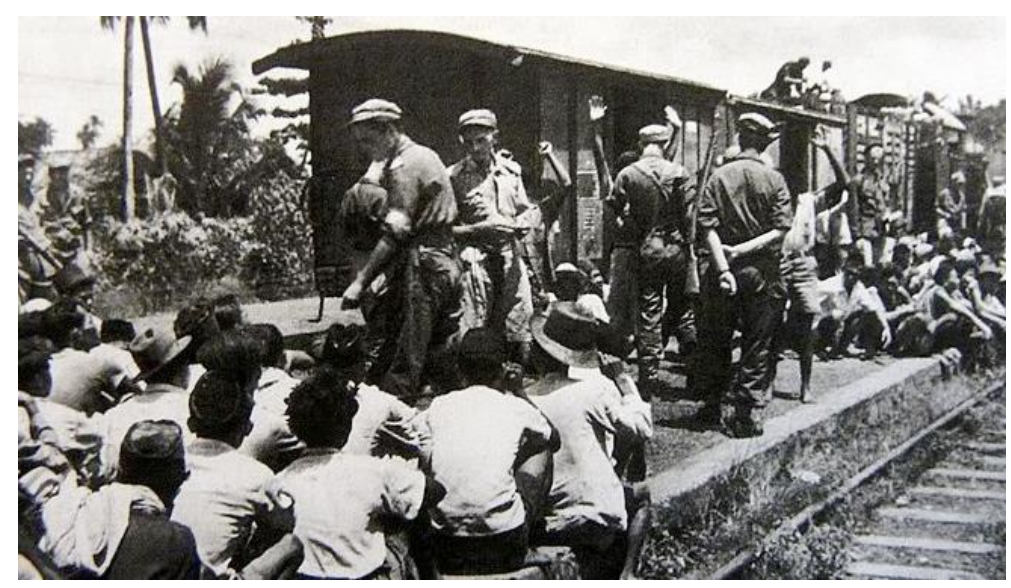

Gambar 8. Foto dokumentasi saat Pak Singgih dan kawan-kawan dimasukkan ke "Gerbong Maut" di Statiun Bondowoso Tgl 28 November 1947, Jam 05.30. Sumber tripodvison.co.uk.diakses 30 Mei 2020

Monomen Gerbong Maut tersebut mengingatkan kita semua, terutama warga masyarakat di Bondowoso akan perjuangan bangsa Indonesia dalam mempertahankan kemederkaan Indonesia dari tangan penjajahan Belanda. Dengan melihat Monomen Gerbong Maut tersebut kita senantiasa diajak untuk merenungkan dan mencamkan peristiwa tanggal 22 Februari 1947 di mana pasukanpasukan Belanda menyerang Bondowoso dan berhasil mendudukinya. Pasukan kita pada waktu itu mengundurkan diri ke gunung-gunung dan melanjutkan perjuangan secara gerilya. Para pemuda pejuang tidak tinggal diam dan hampir setiap malam mereka melakukan serangan-serangan ke maskas V.D.M.B (Veiligheids diendt Mariniers Brigade). Akibat serangan yang dilancarkan secara terus-menerus itu, menyebabkan persedian peluru semakin menipis. Pak Singgih bergerak dalam kota, namun dalam proses penyerangan itu Pak Singgih berhasil disergap Belanda di rumahnya sekitar jam 09.00 pagi pada tgl 20 Serpetember 1947. Sejak hari itu juga Singgih bersama-sama kawan seperjuangan disiksa dengan sangat keji oleh Belanda. Mula-mula mereka di sekap dalam WC selama 
beberapa hari, dan kemudian barulah mereka dipindahkan ke penjara Bondowoso (Prayoga et.al., 1986:50-52).

Pada tgl 28 Novemeber 1947 tengah malam, jelang jam malam masih berlangsung, sekitar jam 01.30 para tawanan dibangunakan dan dengan segera dibariskan satu-persatu. Menjelang pukul 05.30 para tawanan penjara Bondowoso yang berjumlah 100 orang digiring ke Stasiun Bondowoso untuk dimasukkan ke dalam tiga gerbong keretapi dari seng yang tertutup rapat dan tidan diberi kesempatan untuk makan pagi. Pada gerbong pertama memuat 36 orang tawanan, gerbong kedua 34 orang dan gerbong ketiga 30 orang. Dapat dibanyangkan betapa sesaknya udara di dalam gerbong tersebut. Para tawanan tersebut ditutup rapat-apat di dalam gerbong kereta api selama dua jam.dan baru menjelang jam 07.30 barulah diberangkatkan menuju Jember. Ketika kereta tiba di Stasiun Kalisat kurang lebih jam 11.00 siang, sebanyak 6 orang telah menjadi kurban, mati lemas. Di Stasiun Jember, gerbong dijemur selama tiga jam dan tawanan yang meningal bertambah menjadi 12 orang. Salah satu tawanan bernama Slamet Soekarso nomor tahanan 71, meronta-ronta minta air, namun dibiarkan dan kemudian meminum air kencingnya sendiri. Sesampai di Stasiun Probolinggo tawan yang meninggal bertambah menjadi 30 orang. Melihat kejadin itu Pak Singgih yang berumur 53 tahun untuk memanjatkan doa agar mohon pertolongan kepada Tuhan Yang Maha Esa, menurut keyakinan masing-masing (Gambar 8).

Pada pukul 22.00 malam, kereta tiba di Stasiun Wonokromo, Surabaya tempat terakhir dimana mereka akan diturunkan. Setelah tiga gerbong tertutup tersebut dibuka, bagi tawanan yang masih hidup dapat menghirup udara segar. Namun setelah gerbong ketiga yang memuat 30 orang tawanan, dibuka tidak satupun tawasan yang hidup, mereka tewas semua. Berdasarkan pendataan waktu itu 100 tawanan yang masih hidup terdiri atas 12 orang sakit payah, 30 orang dalam kondisi lemas tidak berdaya dan hanya 12 orang tawanan dinyatakan sehat. Bagi mereka yang masih sehat masih diwajibkan mengurus jenasah serta mengurus yang sakit ke Rumah Sakit Karang Menjangan, Surabaya. Setelah kegiatan tersebut selesai tawanan yang dinyatakan sehat langsung dijebloskan dalam penjara Bubutan Surabaya, pada jam 02.00 malam dan ditempatkan di los khusus no.6.

Selama setengah bulan Singgih dan kawan-kawannya menjadi penghuni penjara Bubutan dan beberapa mayat tawanan yang meningal dalam "gerbong Maut" tersebut ada yang dimakamkan di Sidoarjo dan lainnya hingga kini belum terdeteksi. Inilah peristiwa heroik yang mengingatkan kita akan ingatan kolektof tentang nasionalisme yang menginpirasi kita semua bahwa peristiwa ini perlu diwariskan dari generasi ke generasi untuk menanamkan rasa nasionalisme bahwa kemerdekaan Indonesia diperetahankan dengan mengorbankan nyawa dan tenaga. Dalam kaitannya ini maka "monumen Gerbong Maut" (Gambar 9) sebagai simbolisasi untuk senantiasa menum buh kebangkan rasa nasionalisme, khusunya rasa nasionalisme dari pejuang-pejuang muda dari Bondowoso dalm konteks mempertahankan kemederkaan Indonesia. Monumen ini dapat dijadikan aset unggulan "intangible cultural heritage" (Sedyawati 2014: 441-446) untuk menumbuh kembangkan serta melanggengkan rasa nasionalisme yang saat sekarang sudah mulai tergerus. Dari peristiwa ini kemungkinan peristiwa Tgl 28 November 1947 dapat dijadikan even napak tilas 
perjuangan putra daerah, sehingga Statiun Bondowoso dapat ditingkatkan sebagai cagar budaya masa kemnerdekaan karena telah menjdi bukti fisisk adanya peristiwa "Gerbong Maut". Dengan demikian Monumen Gerbong Maut di tengah Kota Bondowoso serta Stasiun Kereta Api Bondowoso dapat dijadikan aset unggulan cagar budaya Bondowoso yang mengandung nilai penting akan perjuangan putra-putra daerah dalam mempertahankan kemerdekaan Indonesia (Prayoga et.al. 1986:50-52, Gambar 10).

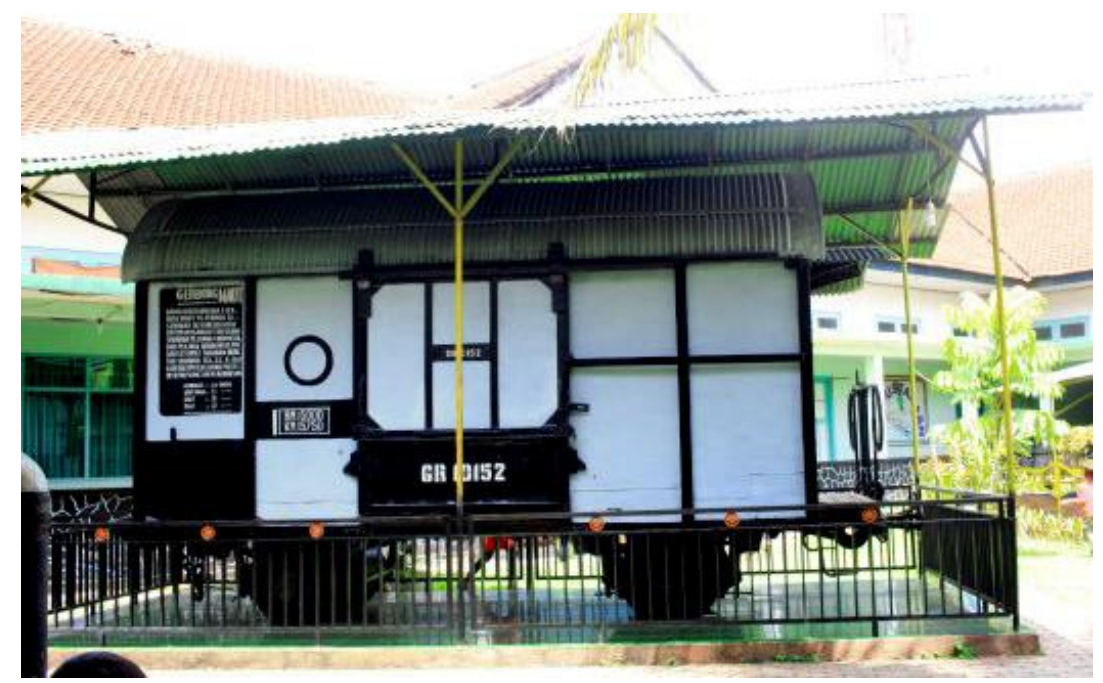

Gambar 9. "Gerbong Maut" dengan no. gerbong. GR 10152 untuk mengangkut tawanan dari Bondowoso ke Surabaya pada tgl 28 Nov 1947 ditetapkan sebagai benda cagar budaya.

(Sumber bombamstic.com. dikases tgl 30 Mei 2020)

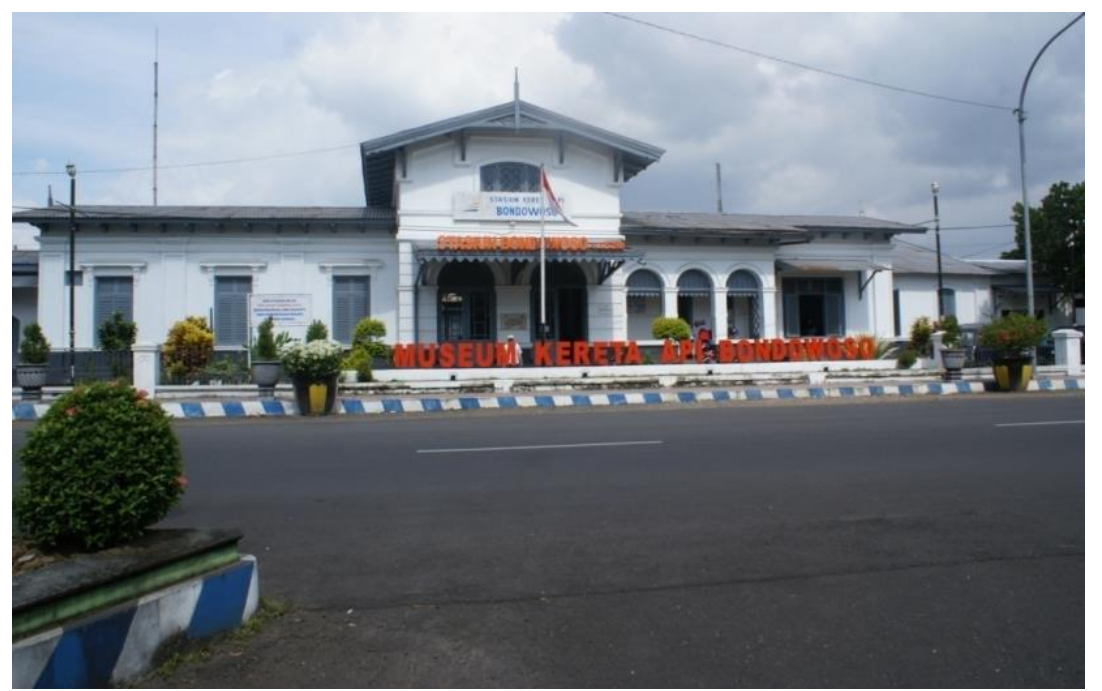

Gambar 10. Statiun Kereta Api Bondowoso yang dibangun Th.1913, ditetapkan sebagai Museum “Gerbong Maut.

(Sumber: Suprapta, 2018) 


\section{PERAN DAN PARTISIPASI MASYARAKAT DALAM UPAYA PEMANFAATAN CAGAR BUDAYA}

Merujuk pada uraian tersebut di atas dapat dikemukakan bahwa potensi serta aset unggulan sumber belajar sejarah lokal dan aset unggulan cagar budaya di Bondowoso dapat dipilahkan menjadi potensi serta aset unggulan sumber belajar sejarah dan aset unngulan cagar budaya berupa kawasan, situs serta bangunan megalitik, situs serta bangunan Hindhu-Budhha, kawasan, situs serta bangunan Kolonial maupun ingatan kolektif : "intangible cultural heritage" berupa peristiwa heroik sejarah yang dikenal dengan "Gerbong Maut". Hal ragam jenis cagar budaya tersebut di atas memiliki nilai budaya, nilai ilmu pengetahuan, nilai sejarah lokal yang sangat tinggi dan tidak ditemukan di tempat lain di Indonesia. Semua itu, hanya terdapat serta berlangsung di daerah Bondwoso. Permasalahan sekarang, bagaimanakah potensi serta aset unggulan cagar budaya tersebut dapat menumbuhkembangkan peran serta partisipasi masyarakat meningkatkan kesejahteraan masyarakat berbasis pada pelestarian cagar budaya. Untuk hal ini. Penulis akan mengajukan gagasan agar peran serta partisipati masyarakat di sekitar situs dapat terwujud serta tidak bertentangan dengan konsep pelestarian cagar budaya.

Model yang penulis usulkan yaitu (a) model peran serta partisipasi masyarakat dalam Even Malang Kembali di Kota Malang berbasis pada penelitian serta pelestarian bangunan Indies di Kota Malang, (b) model peran serta partisipasi masyarakat revitasi bentuk-bentuk rumah gaya Mapajahitan di Trowulan berbasis hasil penelitian serta pelestarian cagar budaya, (c) model peran serta partisipasi masyarakat di sekitar Gunung Pawitra (Penanggungan) berbasis wisata khusus arkeologi : religi dan aventure Gunung Pawitra, dan (d) model peran serta partisipasi masyarakat di kampung warna-warni Kampung Jodipan, Kota Malang berbasis pelestarian lingkungan serta bangunan Indies: rel serta Jembatan Kereta Api.

Baiklah satu persatu kita urai untuk menginpirasi agar peran serta partisipasi masyarakat di sekitar cagar budaya. Model (a) dapat digunakan dengan cara didahului dengan kegiatan ilmiah tentang hasil penelitian bangunan cagar budaya yang mungkin dapat digunakan untuk menumbuhkan peran serta partisipasi masyarakat dalam kaitannya dengan pemanfaatan bangunanbangunan cagar budaya khususnya untuk bangunan Indies atau kolonial di Bondowoso. Dengan pokok kegiatan menghidupkan lagi suasana masa Kolonial lewat nilai-nilai kesejarahan terutama sejarah lokal bangunan Indies di Bondowoso. Setelah itu membuat even yang berhubungan dengan hari jadi Kabupaten Bondowoso untuk menyajikan segala aspek even kebudayaan yang pernah terjadi di Bondowoso selama masa Kolonial Belanda, namun lebih ditonjolkan kehidupan kaum pribumi yang berhubungan dengan sejarah lokal yakni tentang peran utama masyarakat pada waktu itu. Seperti yang di gelar di Even Malang Kembali menampilkan segala aspek kehidupan masa Kolonial Belanda mencakup kesenian, batik, kuliner masa lalu, segala aspek tradisi dan berbagai hal even budaya pada masa Kolonial Belanda ditampilkan kembali. Hal ini akan menggugah masyarakat dalam kaitannya dengan peran serta partisipasi masyarakat dalam proses pemanfaatan aset serta 
unggulan cagar budaya masa Kolonial Belanda: cagar budaya Indies untuk menambah pendapatan masyarakat berbasis pelestarian cagar budaya (Suprapta 2017 a).

Model (b) ini dapat diterapkan untuk menumbuhkembangkan peran serta partisipasi masyarakat dalam kaitannya pemanfaatan aset serta unggulan cagar budaya bangunan-bangunan megalitik. Belajar dari Trowulan dalam kaitannya dengan revitali- sasi hasil penelitian tentang modelmodel Rumah Majapahitan, di lingkungan situs-situs Trowulan, penduduk dibangunkan Modelmodel Rumah Majapahitan. Setelah program pembangunan rumah model Rumah Majapahitan, maka banyak wisatawan datang ke bekas ibu kota Majapahit untuk melihat secara nyata tentang revitalisasi rumah-rumah di Masa Majapahitan Rumah-rumah tersebut dibangun di lingkungan pemukiman penduduk dan difungsikan sebagai penjaja barang-barang industri pariwisata dan bahkan difungsikan juga sebagai rumah penginapan. Kita dapat mencontoh model (b) tersebut dengan merevitalisasi kembali model-model rumah megalitik didasarkan atas hasil penelitian kelompok batu kenong yang masih insitu di Bondowoso. Dalam hal ini bisa kita ambil rekonstruksi rumah panggung megalitik atas dasar penelitian kontruksi denak Kelonpok Batua Kenong I dan II di Grujugan, Pakauman sesuai dengan hasil penelitian W.J.A.Willems dan Blasius Suprapta. Hal ini juga dibarengi tentang revitalisasi rumah-rumah gaya Madura atas hasil arsitektur rumah pemukian Madura Keturunan di sekitar situs-situs megalitik. Sehingga sekaligus menumbuhkembangkan peran serta partisipasi masyarakat berbasis peletarian cagar budaya dan budaya Madura Keturunan di Bondowoso. Revitasi rumah-rumah asli Madura di sekitar situs akan mempunyai daya tarik wisatawan dan sekaligus berperang sebgai sumber belajar sejarah lokal pada keberlangsungan kebudayaan megalithik di Bondowoso serta Revitalisasi tersebut harus didesain berbasisl hasil penelitian dan didirikannya di lingkungan perkampungan penduduk serta dapat dijadikan sebagai rumah penginapan bagi wisatawan seperti halnya rumah-rumah Majapahitan di Trowulan.

Model (c) bisa dikembangkan khusus untuk menumbuh kembangkan peran serta partisipasi masayarakat yang bertempat tinggal di sekitar situs khusunya di sekitaran Gunung Yaang. Model (c) ini sekarang telah dikembangkan untuk menumbuh kem-bangkan peran serta partisipasi masyarakat di sekitar Gunung Penanggungan (Pawitra) untuk membentuk wisata pendakian gunung berbasis pada pelestarian cagar budaya Penanggungan serta pelestarian lingkungan. Dengan demikian berbasis pada pemanfaatan sebaran situs megalitik di lereng timur Gunung Yaang dapat dikembangkan wisata khusus (pendakian gunung) maupun wisata sejarah lokal sehingga hal ini lambat laun akan menambah pendapatan penduduk di sekitar lereng timur Gunung Yaang.

Adapun model (d) merupakan contoh model yang sangat sederhana dan biaya murah untuk menumbuhkembangkan peran serta partisipasi masyarakat untuk menjadikan kampung warnawarni Kapung Judipan, Kota Malang sebagai destinasi wisata kampung. Dengan menggunakan lingkungan Kali Brantas dan dipadukan dengan keelokan Jembatan Rel Kereta Api yang dibangun pada masa Kolonial Belanda, maka penduduk setempat melalui sponsor cat tidak berkeberatan mencat seluruh rumah dengan cat warna-warni. Even ini menarik perhatian para pemerhati fotografer serta nitizen, sehingga hari demi hari pengunjung ke kampung wisata bertambah padat. 
Dan dalam berebagai even, pengembangan wisata kampung ini didukung sepenuhnya oleh Pemerintah Kota Malang. Dalam pengamatan saya, selama satu minggu, seluruh yang berkaitan dengan pengelolaan wisata kampung diurus oleh pengurus kampung yang perlu diketahui satu sama lain saling bahu-membahu. Tidak ada yang merasa piter sendiri, tapi dengan penuh semangat serta kerendahan hati semua bersatu-padu ikut berperan serta berpartisipasi dalam menggiatkan wisata kampung warna-warni di sekitar cagar budaya bangunan Indies atau kolonial. Berkaca dari pengembangan model (d) tersebut di sekitaran situs cagar budaya megalithic dirintis berdirinya perkampungan megalithik yang menampilkan tata cara adat penguburan, berbagai ragam tata pamer bangunan megalithic dan disertai informasi berdasarkan kajian dan penelitian. Kemungkinan Pusat Informasi Megalitik yang dibangun di Pakauman, Grujugan bisa dikembangkan ke arah Perkampungan Megalithik. Hal ini akan menjadi sumber belajar sejarah lokal (Sayer, 2015) yang terkait dengan informasi tentang aset unggulan cagar budaya daerah Bondowoso.

\section{SIMPULAN}

Berdasarkan uraian tersebut di atas, maka dapat disimpulkan tentang bagaimakah strategi untuk mnumbuh-kembangkan peran serta partisipasi masyarakat untuk pemanfaatan aset serta unggulan cagar budaya dalam kaitannya dengan sumber belajar sejarah lokal serta kesejahteraan masyarakat di sekitar situs berbasis pada pelestarian cagar budaya. Ada tiga hal yang perlu diperhatian yaitu (1) perang penting pembuat kebijakan dalam hal ini adalah peran Pemerintah Kabupaten Bondowoso antara lain Dinas Pendidikan setempat mewajibkan peserta didik untuk mengunjungi situs cagar budaya, (2) peran peneliti untuk mengkaji tentang nilai penting, nilai kesejarahan termasuk sejarah lokal, nilai ilmu pengetahuan serta nilai baudaya bagi pengembangan sejarah lokal atau budaya lokal dan hal ini terkait dengan peran para peneliti, tim ahli cagar budaya Bondowoso serta tim Pelestari cagar budaya Bondowoso dan (3) adalah perang serta partisipasi masyarakat di sekitar situs yang dalam hal ini bisa berasal dari perseorangan, penduduk di sekitar situs serta komunitas tentang pemerhati pelestari cagar budaya Bondowoso. Ketiga hal tersebut harus saling sinegergi serta bahu-membahu, tidak ada yang merasa pinten sendiri, mau menang sendiri tetapi bersatu dengan niat bail untuk melestarikan aset serta unggulan sumber belajar sejarah lokal dan aset unggulan cagar budaya Bondowoso untuk kesejahteraan masyarakat di sekitar situs.

Ada beberapa model yang dapat dikembangkan dalam kaitannya dengan menumbuhkembangkan peran serta partisipasi masyarakat tentang pemanfaatan cagar budaya untuk kesejahteraan masyarakat. Apakah akan dikembangkan dengan model (a), model (b), model (c) maupun model (d) atau kombinasi berbagai model. Hal yang dimaksud perlu dikomunikasikan pada masyarakat Bondowoso memiliki aset serta unggulan cagar budaya dari lintasan masa tradisi parsejarah, masa Hindhu-Buddha, masa Kolonial dan masa Kemerdekaan Indonesia. Sebagai penutup, semoga gagasan penulis ini berguna sebagai salah satu referensi untuk menumbuh kembangkan peran serta partisipasi masyarakat di sekitar situs-situs di Bondowoso dalam kaitannya dengan pemanfaatan cagar budaya berbasis pelestarian untuk kesejahteran masyarakat. 


\section{DAFTAR RUJUKAN}

Ardika, I.G. (2012). Pariwisata Minat Khusus Berbasis Arkeologi, dalam Arkeologi Untuk Publik, Jakarta: Ikatan Ahli Arkeologi Indonesia.

bombastis.com. Foto Dokumentasi Para Bumiputra Bondowoso Dimasukkan ke "Gerbong Maut" di Stasiun Kereta Api Bondowoso oleh Tentara Belanda Pada Tgl.28 November 1947 Jam 05.30, diakses tgl 30 Mei 2020

Handini, R. (2012). Menghidupkan Kembali Situs-situs Living Megalithic Sebagai Destinasi Wisata: Melihat Sekarang-Melihat Masa Lalu dalam Arkleologi untuk Publik. Jakarta: Ikatan Ahli Arkeologi

Kementrian Kebudayaan dan Pariwisata, Direktorat Sejarah Jendral Sejarah dan Purbakala. (2013). Undang-Undang Republik Indonesia Nomor 11 Tahun 2010 Tentang Cagar Budaya. Jakarta: Kementerian Kebudayaan dan Pariwisata

Leirissa, R.Z. (1984). Nusantara di Abad Ke-18 dan Ke-19 dalam Sejarah Nasional Indonesia Jilid IV, Jakarta: Balai Pustaka, Kementrian Pendidikan dan Kebudayaan

Prasetyo, B. (2014). Peranan Megalitik dalam Pembentukan dan Pewarisan Budaya Nusantara, (Pidato pengukuhan guru besar riset), Jakarta: Pusat Penelitian Arkeologi Nasional, Kementrian Pendidikan dan Kebudayaan-Lembaga Ilmu Pengetahuan Indonesia

Sanjaya, W. (2013). Perencanaan \& Desain Sistem Pembelajaran. Jakarta: PT Fajar Interpranata Media Sanjaya, W. (2014). Media Komunikasi Pembelajaran. Jakarta: PT Fajar Interprtama Media

Sayen, F. (2015). Public History: A Practical Guide, London: Bloomsbury Publishing

Sedyawati, E. (2014). Pengertian "Tangible" dan "Intangible" dalam Wacana tentang Warisan Budaya", dalam Kebudayaan di Nusantara: dari Keris Tor-to sampai Industri Budaya, Depok: Komunitas Bambu, hlm. 441-446

Soejono, R.P. (1984). "Jaman Prasejarah di Indonesia" dalam Sejarah Nasional Indonesia Jilid I. Jakarta: Balai Pustaka, Departemen Pndidikan dan Kebudayaan

Steinmtz, H.E. (1898). "Oundheidkundige beschrijving van de Afdeeling Bondowoso (Residen Besoeki)" T.B.G XL, hlm.1-60

Sukiman, D. (2000). Kebudayaan Indis dan Gaya Hidup Masyarakat Pendukungnya di Jawa (Abad XVIIIMedio Abad XX), Yogyakarta: Yayasan Bentang Budaya

Sumadio, B. (1993). "Jaman Kuno" dalam Sejarah Nasional Indonesia jilid II, Jakarta: Balai Pustaka, Departemen Pendidikan dan Kebudayaan

Supardi, N. (2012). Arkeologi untuk Masyrakat-Masyarakat untuk Arkeologi dalam Arkeologi untuk Publik, Jakarta: Ikatan Ahli Arkeologi Indonesia, hlm.125-133

Suprapta, B. (1987). Fungsi Batu Kenong Daerah Grujugan: Analisis Struktur Denah dan Temuan Serta, Skripsi Sarjana S.1 (tidak terbit), Yogyakarta: Fakultas Sastra, Universitas Gadjah Mada 
Suprapta, B. (2017a). Model Pemanfaatan "Cagar Budaya" untuk Kesejahteraan Masyarakat: Studi Kasus: Even Malang Kembali. Sejarah dan Budaya: Jurnal Sejarah, Budaya dan Pengajarannya, 10, (1), Nomor 1, 11-28.

Suprapta, B. (2017b). Nilai-Nilai Pendidikan Karakter dalam Relief Cerita Tantri: Perpektif Strukturalisme Lévi-Strauss. Yogyakarta: Penerbit PT KanisiusSuprapta, B. (2018). Pemanfaatan Cagar Budaya di Kabupaten Pacitan sebagai Media Penunjang Pendidikan Sejarah. Jurnal Pendidikan Sejarah Indonesia, 1, (1), 85-102.

Suprapta, B. (2000). Tinjauan Sejarah Kesenian Tentang Bangunan Megalitik Kubur Batu di Daerah Bondowoso, Jawa Timur, Sejarah Kajian Sejarah dan Pengajarannya, Tahun kelima, Noomor 7, hlm76 - 95

Suprapta, B. (2019). Laporan Penggalian Kubur Bilik PKM 1, Bondowoso, Jawa Timur (tidak terbit), Malang: Fakultas Ilmu Sosial, Universitas Negeri Malang tripadvison.co.uk. (2020). Foto “Gerbong Maut no.Gerbong GR.10152" Ditetapkan sebagai Benda Cagar Budaya di Museum Brawijaya Malang, diakses pada Tgl 30 Mei 2020 van Heekeren, H.R. (1931) Megalithische Overblijfsilen in Besoeki, dalam. DJAWA XI, hlm.1 - 18. Willems, W.J.A. (1938). "Het onderzoek der megalithe te Pakaoeman bij Bondowoso" dlm. ROD III 